$1-1-1987$

\title{
EERS (Economic Evaluation of a Residue System) : a model for analyzing the economics of installing a steam kiln and wood-fired boiler at a West Virginia sawmill
}

\author{
David R. Walton \\ David Walter Patterson \\ James P. Armstrong
}

Follow this and additional works at: https://researchrepository.wvu.edu/ wv_agricultural_and_forestry_experiment_station_bulletins

\section{Digital Commons Citation}

Walton, David R.; Patterson, David Walter; and Armstrong, James P., "EERS (Economic Evaluation of a Residue System) : a model for analyzing the economics of installing a steam kiln and wood-fired boiler at a West Virginia sawmill" (1987). West Virginia Agricultural and Forestry Experiment Station Bulletins. 696.

https://researchrepository.wvu.edu/wv_agricultural_and_forestry_experiment_station_bulletins/590 


\section{EERS (Economic Evaluation of a Residue System):}

A Model for Analyzing the Economics of Installing a Steam Kiln and Wood-Fired Boiler at a West Virginia Sawmill

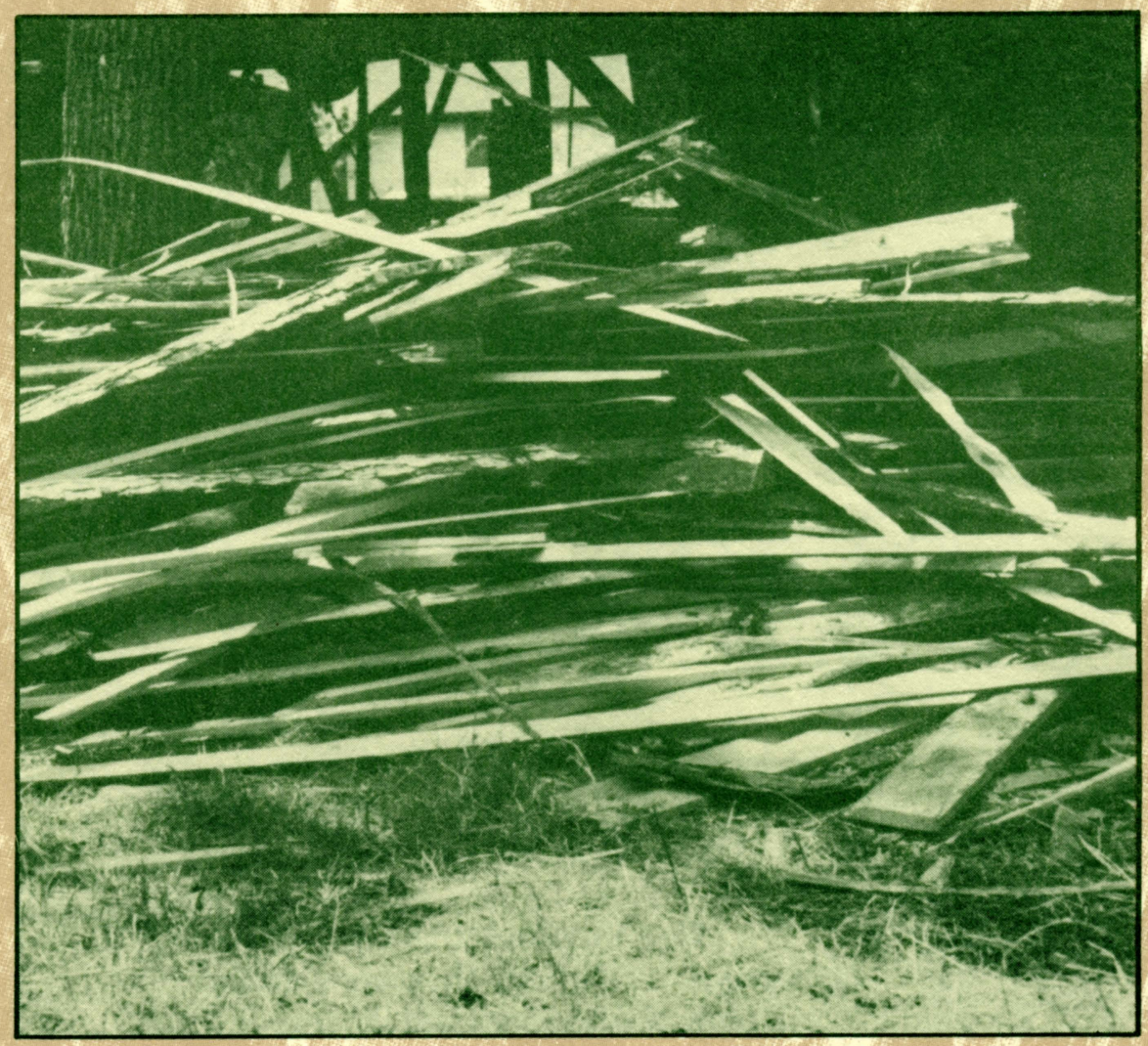

Agricultural and Forestry Experiment Station West Virginia University 


\section{Authors}

David R. Walton is former graduate student in the Division of Forestry, and David W. Patterson and James P. Armstrong are assistant forest scientists, Agricultural and Forestry Experiment Station.

West Virginia University

Agricultural and Forestry Experiment Station

College of Agriculture and Forestry

Robert H. Maxwell, Director Morgantown 


\section{Contents}

Part I: Preliminary Considerations $\ldots \ldots \ldots \ldots \ldots \ldots \ldots \ldots \ldots \ldots \ldots$

Mill Data Summary................................. 1

Value Added Due to Kiln Drying $\ldots \ldots \ldots \ldots \ldots \ldots \ldots \ldots \ldots \ldots \ldots \ldots$

Equipment Available ............................... 3

Parameters Needed for the Analysis ...................... 9

Conclusions and Recommendations $\ldots \ldots \ldots \ldots \ldots \ldots \ldots \ldots \ldots, 11$

Part II: EERS User's Guide $\ldots \ldots \ldots \ldots \ldots \ldots \ldots \ldots \ldots \ldots \ldots \ldots \ldots 11$

Computer Hardware and Software Requirements $\ldots \ldots \ldots \ldots \ldots \ldots 12$

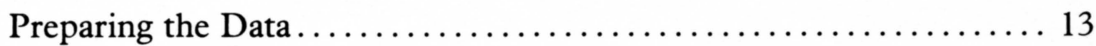

Data Needed for the Analysis ......................... 14

How to Load and Run the Program $\ldots \ldots \ldots \ldots \ldots \ldots \ldots \ldots \ldots \ldots$

Interpreting the Output $\ldots \ldots \ldots \ldots \ldots \ldots \ldots \ldots \ldots \ldots \ldots \ldots \ldots \ldots$

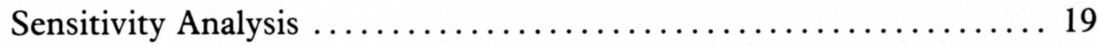

Worksheets .................................. 20

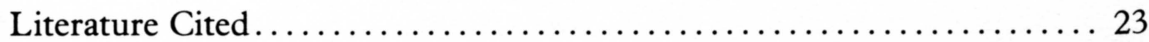


[Blank Page in Original Bulletin] 


\section{EERS (Economic Evaluation of a Residue System): \\ A Model for Analyzing the Economics of Installing a Steam Kiln and Wood- Fired Boiler at a West Virginia Sawmill}

David R. Walton, David W. Patterson, James P. Armstrong

Kiln drying is the first step in adding further value to hardwood factory lumber once it is sawn. Not only is the value of lumber increased but also the marketplace is expanded significantly. On the other hand, kiln drying is energy intensive and the cost of installing and operating a dry kiln facility can be substantial. Metz (1985) estimated a cost of $\$ 1.2$ million for kiln, boiler and related equipment for a $200 \mathrm{MBF}$ (thousand board feet) capacity conventional steam-heated kiln system fueled with sawmill residue. An additional $\$ 1.46$ million was estimated for initial inventory. These high capital outlays make kiln drying an investment which requires in-depth economic analysis to determine its economic feasibility.

A study was conducted at West Virginia University to develop a computer decision model to help sawmill owners determine the economic feasibility of installing dry kilns and a sawmill residue fueled boiler. A great deal of preliminary research was done in order to develop a model which would give useful and dependable results. The purpose of this bulletin is to identify the key factors in developing a useful economic analysis and to present the user's guide for the computer model EERS (Economic Evaluation of a Residue System).

\section{Part 1: Preliminary Considerations}

\section{Mill Data Summary}

Twenty-seven wood products facilities in West Virginia were visited. At each facility an informal interview was conducted with the managers. Topics discussed included:

1. lumber production (species, volume, grade);

2. residue production (chips, bark, sawdust);

3. lumber and residue markets;

4. kiln drying status; and

5. fuel usage. 
The facilities studied represent a diverse sampling of wood products operations that include primary and secondary processing. Nineteen of the facilities were operating dry kilns. Of these, one was operating hot water kilns and one was operating a small solar-heated kiln. The rest of the kilns were steam heated.

An average of 47 percent of the lumber cut was grade 1 Common and better. The actual mill percentages ranged from 43 percent to 54 percent. Approximately 80 percent of the lumber cut at the mills was grade 2 Common and better. The range in this group was 66 percent to 100 percent. These percentages are in close agreement with Hanks et al. (1980). The mills with dry kilns reported drying an average of 35 percent of their total lumber production. The actual percentages ranged from 25 percent to 48 percent. At the mills not using sawmill residue as a fuel source for the kilns, the average kiln drying fuel cost was $\$ 32.50$ per $\mathrm{MBF}$. These costs ranged from $\$ 28.00$ per $\mathrm{MBF}$ to $\$ 37.00$ per MBF. Table 1 contains a summary of the average residues produced at the sawmills and the range for each type.

Table 1

Average residue production at sawmills visited.

\begin{tabular}{llr}
\hline Residue & Average & \multicolumn{1}{l}{ Range } \\
\hline Chips & $2263 \mathrm{lbs} / \mathrm{MBF}$ & $1263-2797$ \\
Bark & 1564 & $899-2230$ \\
Sawdust & 1426 & $1168-1685$ \\
Sawdust \& Bark & 2926 & $2067-3915$ \\
\hline
\end{tabular}

Managers were also asked about any problems they were encountering or might encounter which would be relevant to the project. Some of the managers using kilns stated that the expanded market for kiln dried lumber had been a key factor in their survival of the economic slump of the early 1980's.

At the eight mills using natural gas heat, most of the managers stated that heating cost was a major item in their operating budget. Others stated that they will go out of business if they do not reduce their heating cost drastically by switching to wood residue as an energy source. Since visiting these mills in 1983, three of the gas burning mills have converted their boilers to wood residue and two others were forced to shut down their kilns because of high energy costs.

\section{Value Added Due to Kiln Drying}

In order to assess the expected increase in lumber value due to kiln drying, an investigation of historic data was conducted. The difference between air dried and kiln dried prices for hardwood lumber was compiled for the years 1971 
through 1984. Four species were studied: red oak, white oak, yellow-poplar, and black cherry. Two thicknesses $\left(4 / 4^{\prime \prime}\right.$ and $\left.8 / 4^{\prime \prime}\right)$ and two grade groupings (FAS $+1 \mathrm{~F}$ and $1 \mathrm{C}$ ) were studied for each species. Kiln dried and air dried prices were examined at four-month intervals over the 14-year period. Air dried prices were based on the Appalachian Hardwoods page of the Hardwood Market Report. These prices represent average market prices for carload quantities of rough, air dried, random lengths and widths, F.O.B. at the mill. Kiln dried prices were taken from the Anderson-Tully Company advertisement which appears regularly in the Hardwood Market Report. These prices represent Anderson-Tully's price for carload quantities of kiln dried, random lengths and widths, F.O.B. at the mill and not necessarily the true market price with premiums for FAS \& $1 \mathrm{~F}$.

Figures 1-4 show the difference in kiln dried and air dried prices for the period 1971 to 1984 for red oak, white oak, yellow-poplar, and black cherry, respectively. It is apparent from Figures 1,2 , and 3 that the value added due to kiln drying has increased steadily over the past 14 years. This increase is probably due in part to the increase in fossil fuel costs over the same period. In Figure 4 it is shown that the value added due to kiln drying cherry has remained relatively stable over the 14-year period. This may be due to a decreased demand for kiln dried cherry over time or it may simply reflect the ability of Anderson-Tully Company to sell kiln dried cherry at a price close to the average air dried price.

Consider a fictitious company which had been operating dry kilns since 1971 and had been drying primarily red oak, white oak, and yellow-poplar, which are the most frequently dried species in West Virginia (Armstrong 1984). If the company had been using natural gas to heat its kilns, most of the increase in value added due to drying would have been offset by a 29 percent annual increase in its gas bill (U.S. Department of Energy 1982). If, on the other hand, the company had been using sawmill residue to heat its kilns, its heating costs would not have increased substantially so that the value added would show up as profit and not be absorbed in energy costs. If the trends shown in Figures 1, 2,3 , and 4 continue and the cost of fossil fuels does not decrease substantially, sawmill residue will remain an attractive fuel source.

The single most important bit of information revealed by this analysis was that the value added due to kiln drying for hardwood lumber is dependent on several factors-including species, thickness, and grade of the lumber. Therefore, a good economic analysis tool will have to take into account the exact product mix of a company in order to be effective.

\section{Equipment Available}

Kiln and boiler manufacturers were contacted to determine the availability and characteristics of dry kiln and wood fueled boiler equipment applicable to West 


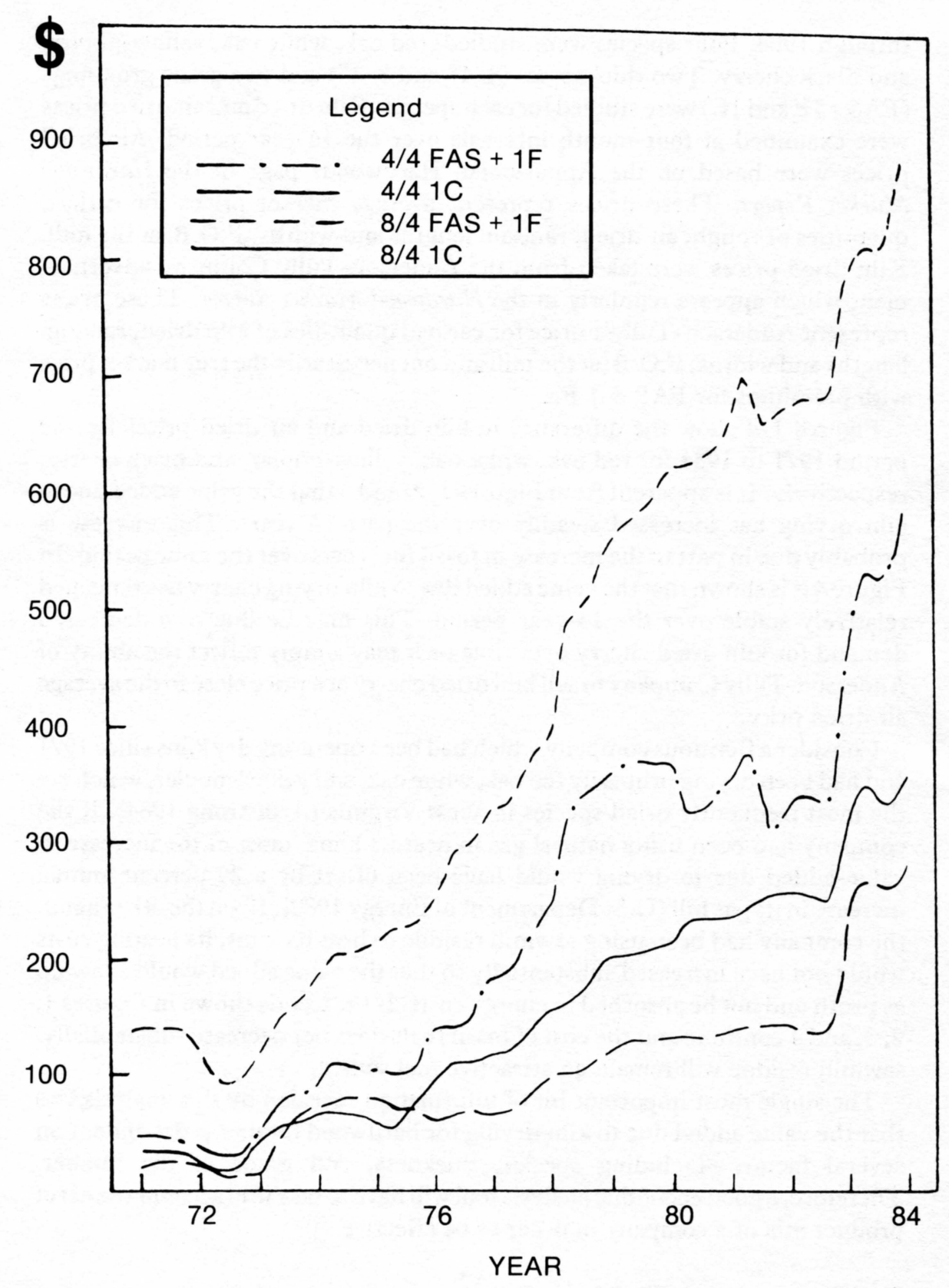

Figure 1. Difference between air-dried price and kiln-dried price for different thicknesses and grades of red oak lumber. 


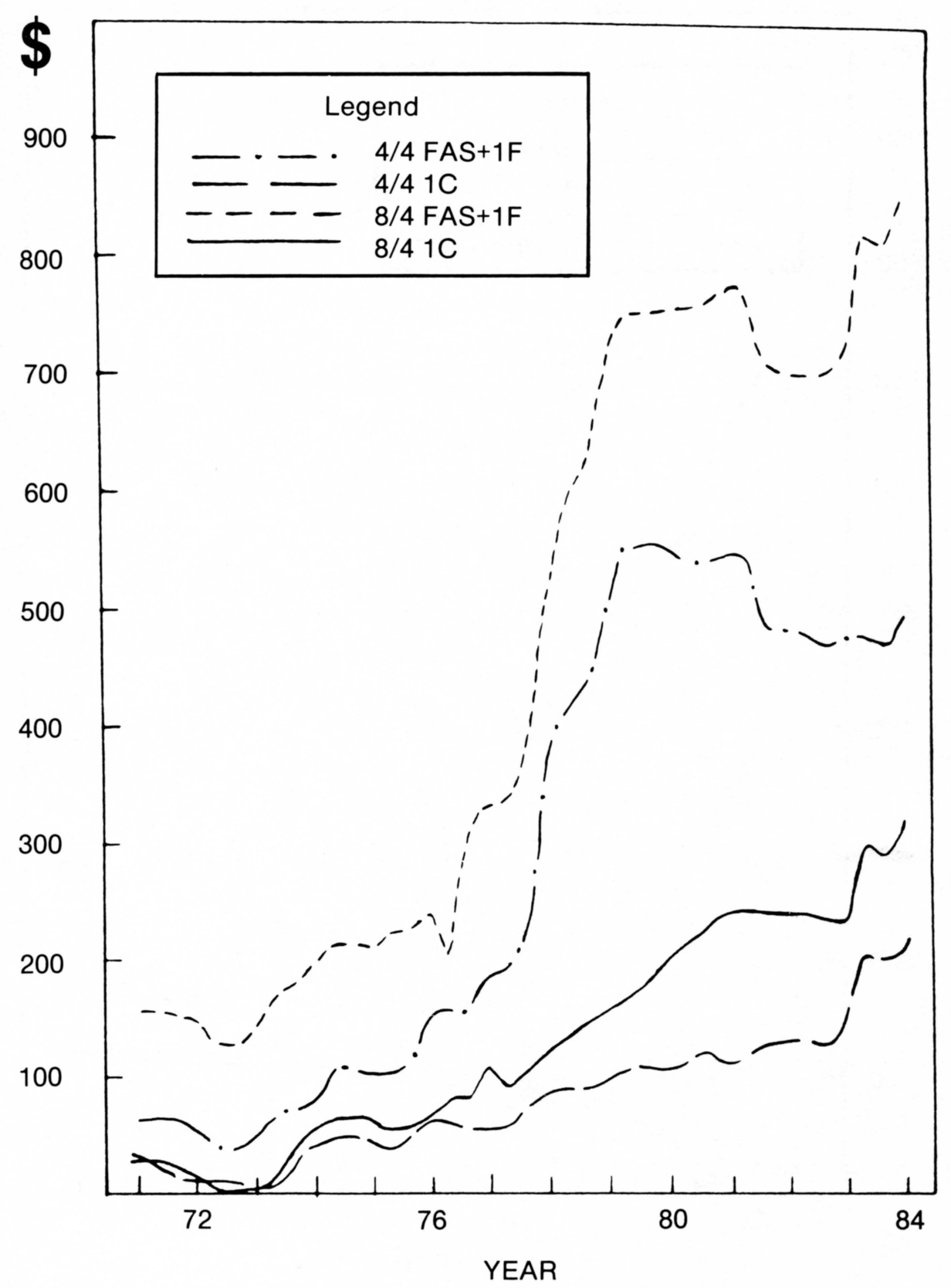

Figure 2. Difference between air-dried price and kiln-dried price for different thicknesses and grades of white oak lumber. 


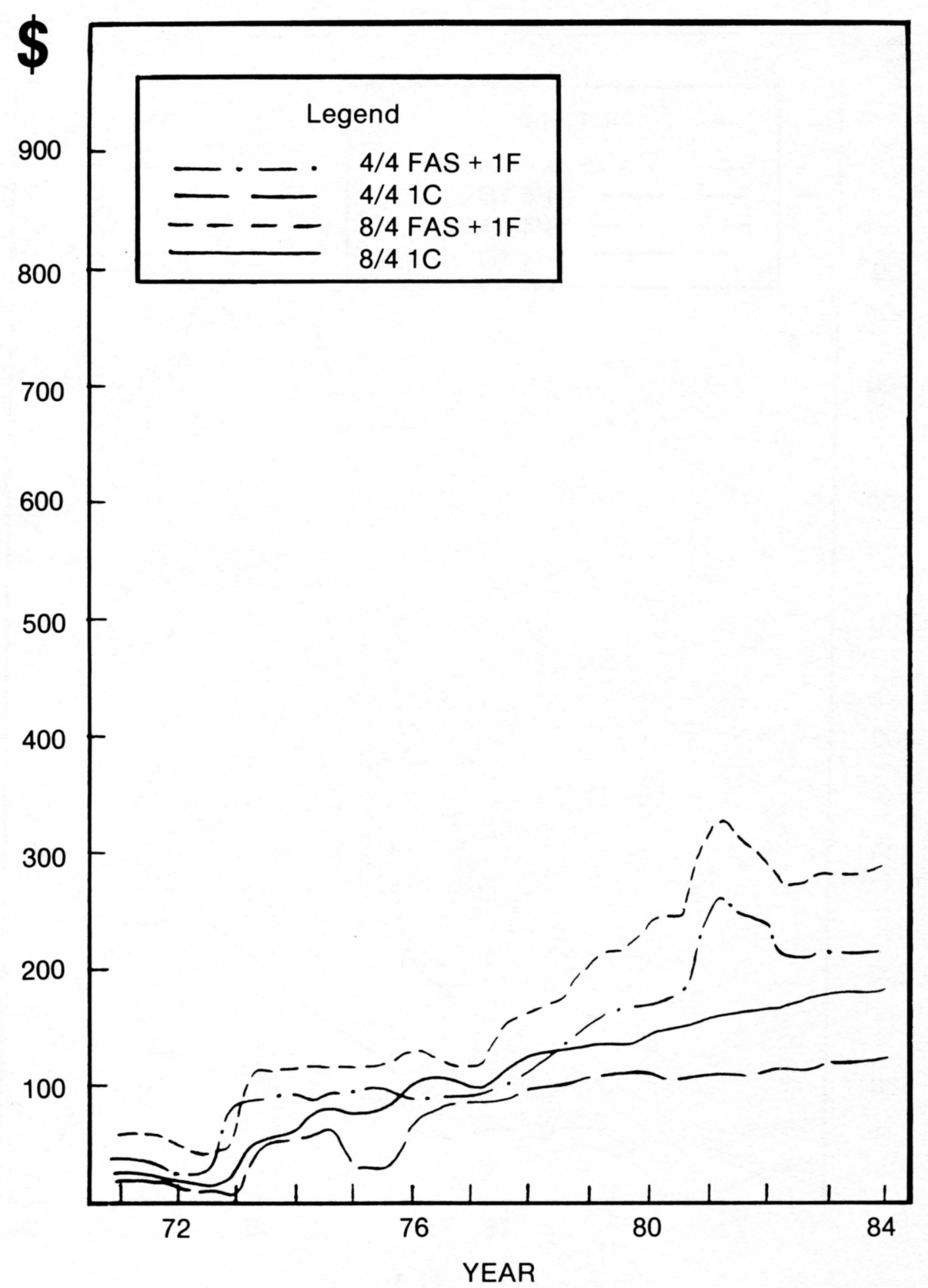

Figure 3. Difference between air-dried price and kiln-dried price for different thicknesses and grades of yellow-poplar lumber. 


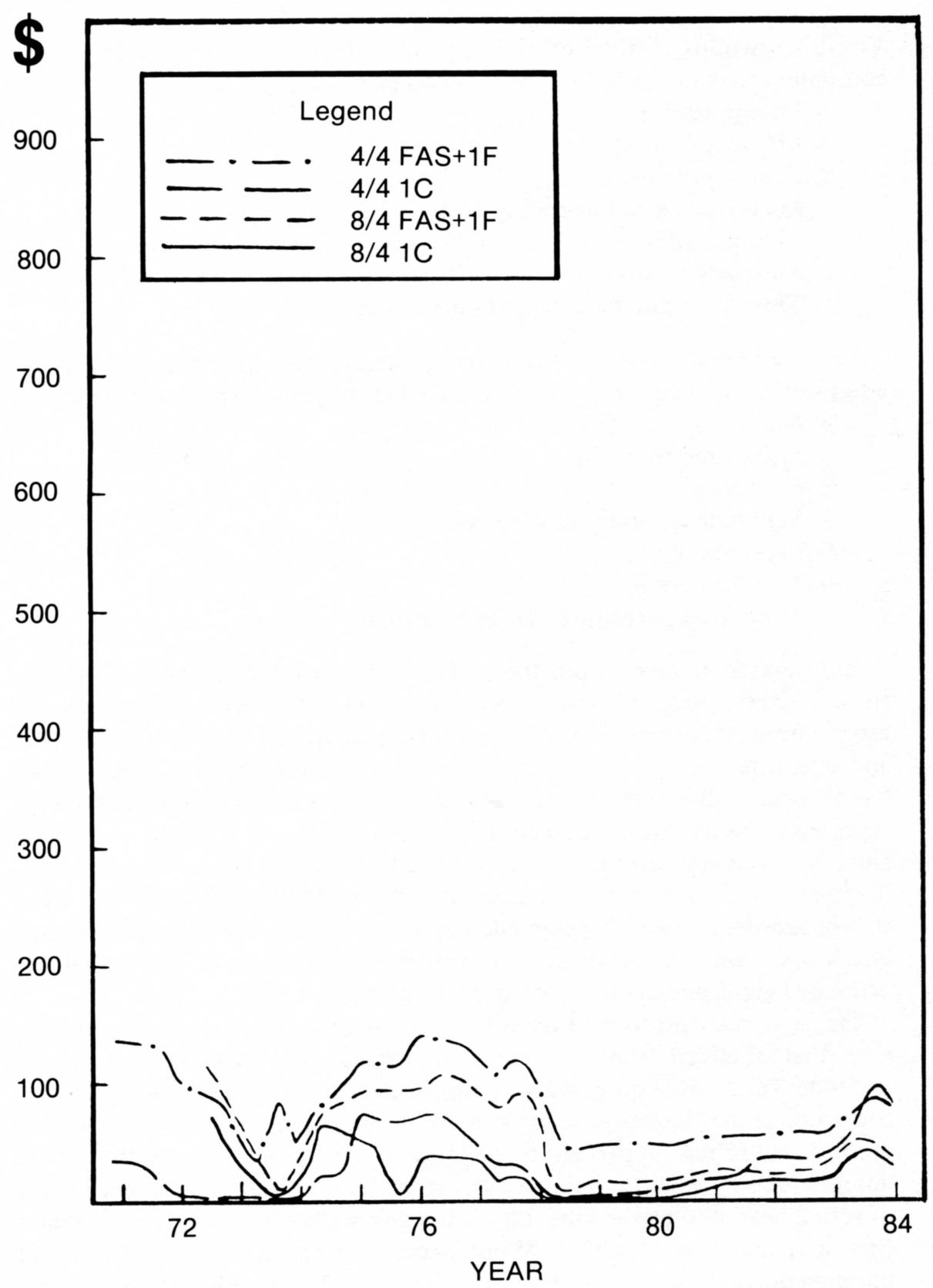

Figure 4. Difference between air-dried price and kiln-dried price for different thicknesses and grades of cherry lumber. 
Virginia sawmills. A total of 57 companies which produce or install boiler equipment were contacted by mail and asked to supply information on:

1. Energy output

2. Efficiency ratings

3. Fuel requirements

4. Maintenance and operating costs

5. Expected life

6. Turn-key cost

7. Time from purchase order to operating

Letters were also sent to 14 companies manufacturing or installing dry kiln equipment. The kiln companies were asked to supply information concerning:

1. Kiln capacity

2. Energy requirements

3. Efficiency

4. Maintenance and operating costs

5. Expected life

6. Turn-key costs

7. Time from purchase order to operating

Information received from the boiler companies covered boilers ranging from 36-BHP (boiler horsepower) to over 1500-BHP. Operating efficiencies ranged from 50 percent to over 90 percent depending on fuel type, boiler type, and operating conditions. Information was received on boilers which would handle nearly all fuel types and sizes. Maintenance and operating costs were reported to be less than 2 percent of the equipment cost annually but varied from one system to the next. Expected life was listed at no less than 20 years. Turn-key costs ranged from under $\$ 200,000$ to $\$ 1,000,000$. The time from purchase order to operating depended upon the distance the product needed to be shipped and on the degree of customization. Many of the companies estimated eight months to a year until operating.

The information received from the kiln manufacturers was less complete than that obtained from the boiler companies. Kiln capacity is customer dependent and can be designed to fit almost any need. Energy requirements are a function of the kiln schedule and size. Efficiency ratings for drying hardwoods are low, at around 30 percent to 40 percent. This represents the theoretical amount of heat needed to remove water from the wood, divided by the amount of actual heat used by the kiln. This is in agreement with Wengert (1974) and Shottafer and Shuler (1974). Maintenance and operating cost varied with equipment type (i.e., internal or external fans). Expected life was approximately 20 to 30 years. Turn-key costs were variable depending on the capacity needed. The time from purchase order to operating was variable but usually less than that for boilers. 
The most important information obtained from contacting the kiln and boiler companies was that each boiler and kiln operation is unique. Each will have its own problems and miscellaneous costs. Therefore, it is evident that in order for an economic analysis tool to be useful and effective it must be as site specific as possible. It is in this context that a decision model should be built. The model must be flexible, so as to permit use by a wide range of companies that may differ significantly.

\section{Parameters Needed for the Analysis}

The mill, lumber price, and equipment data were used to develop a working list of parameters needed for an economic analysis. This list, which follows, represents all factors which need to be considered in analyzing a project under the constraints given.

1. Equipment Configuration
A. Boiler
size
efficiency
cost (initial, fixed)
B. Dry Kiln
capacity
efficiency
cost (initial, fixed)
number of operating days
C. Predrier
cost (initial, fixed)

2. Lumber Production
A. Volumes
species
thickness
grade
B. Green or Air Dried Price
species
thickness
grade
C. Kiln Dried Price
species
thickness
grade

3. Drying
A. Initial Moisture Content
B. Final Moisture Content 
4. Residue Production
A. Chips
volume
moisture content
B. Bark
volume
moisture content
C. Sawdust
volume
moisture content
D. Residue Opportunity Cost

5. Miscellaneous Cost
A. Initial
equipment (forklifts, stackers, etc.)
inventory
other (stickers, land, etc.)
B. Annual
equipment
other (insurance, etc.)

6. Tax Environment
A. Effective Tax Rate
B. Depreciation Schedule
C. Tax Credits
D. State Taxes

7. Cost of Capital
A. Loan Interest Rate
B. Loan Period
C. Amount Borrowed
D. Alternative Investment Rate for Firm's Own Money
E. Desired Rate of Return

8. Inflators/Deflators
A. Kiln Operating Costs
B. Boiler Operating Costs
C. Predrier Operating Costs
D. Cost of Residues Purchased
E. Revenues from Sale of Residues
F. Kiln Drying Revenues

This list of parameters can be used as a checklist to make sure that all aspects of the proposed operation are considered in the analysis. It should be noted that this list is a summary of the parameters and in the actual analysis many of the parameters listed should be considered in much more detail than given here. 
Several other parameters which are not site specific have been built into the EERS program, such as the heating value of different species of wood and the approximate relative drying times for different species and thicknesses of lumber.

\section{Conclusions and Recommendations}

It is important that sawmill managers fully understand the probable cash flows and operating environment of a capital intensive project such as kiln drying before undertaking the operation. Current practices in engineering economy allow them to do this in an accurate manner provided that they take into account all parameters which will have an effect, either directly or indirectly, on the economic performance of the project. In the case of conventional kiln drying of hardwood lumber, this research has shown that site specificity is the key to a complete and accurate economic analysis. As many variables as possible should be considered, including: equipment configuration, lumber production and market, drying regime, residue production, miscellaneous job specific costs, tax environment, cost of capital, and projected inflation rates. An analysis of this magnitude can be time-consuming and costly. The benefits of such an analysis, however, far outweigh the possible costs of not conducting it.

\section{Part II: EERS User's Guide}

EERS (Economic Evaluation of a Residue System) is an interactive economic analysis program designed for use by sawmill owners who are considering installing conventional steam heated dry kilns and a wood residue fired boiler. The "user friendly" program is designed to take the user step-by-step through data entry and will provide the following useful information:

A. Species by species summaries of current and expected revenues as well as the marginal revenue expected from the project.

B. A reference estimate of the required kiln capacity.

C. Useable heat requirements for drying the lumber entered.

D. Energy available from current residues (bark, chips, sawdust).

E. Loan repayment schedule for the project.

F. Yearly cash flow summary.

G. Itemized cash flow summary.

$\mathrm{H}$. Economic decision criteria including:

1. Net Present Value (NPV)

2. Internal Rate of Return (IRR)

3. Payback Period

4. Benefit/Cost ratio (B/C)

5. Return on Invested Capital (ROI)

6. Average Net Pre-Tax Profit over 10 years 


\section{Average ROI over 10 years}

I. Current inputs and parameters

In addition to providing this information, the program features an interactive user-defined sensitivity analysis which allows the user to change the values of any or all of the input variables to determine the effect of each variable of interest on the economic criteria.

EERS provides a site specific analysis which is applicable to all mills in West Virginia meeting the previously mentioned conditions. With some modifications to the tax computation subroutine, the program may be used in any state. The program is limited in the sense that the economic output and cash flows are only representative of the input parameters. Any change in conditions during the life of the project will result in different economic returns. The old computing rule of "garbage in-garbage out" also applies. In other words, the economic analysis provided by EERS is only as good as the data which is supplied by the user.

The purpose of this user's guide is to help the user prepare data needed, assist in the running of the program, and help the user interpret the output of the program.

\section{Computer Hardware and Software Requirements}

EERS was written in Applesoft Basic on an Apple II+ microcomputer. In order to run the program you will need the following:
A. An Apple II or compatible system which supports Applesoft Basic.
B. One disk drive and DOS 3.3 or a compatible disk operating system.
C. At least $48 \mathrm{~K}$ of RAM.
D. A printer is optional, but if one is used it must be attached to peripheral slot \#1.

\section{Preparing the Data}

In the back of this user's guide you will find a worksheet (A-1) which you should use to prepare your data for the computer analysis. Each numbered paragraph in the next section of the manual refers to one piece of data which is needed for the analysis. After reading each paragraph, turn to the same number line in the worksheet and enter the appropriate data. Some of the data may require a bit of homework to come up with a good representative figure. Be sure to carefully read each paragraph to make sure you are giving the program exactly what it is asking for. It is a good idea to make copies of the worksheet before you use it for later analyses. 


\section{Data Needed for the Analysis}

\section{Kiln Capacity}

This is simply the board-foot capacity per charge of the kiln you plan to install.

\section{Kiln Efficiency}

This number represents the efficiency at which the kiln you are considering can dry hardwood lumber. Kiln efficiency is the ratio of the theoretical heat needed to remove the moisture from the wood to total heat required in the kiln. The number can be obtained from the kiln manufacturer. If you cannot obtain an estimate from the manufacturer, enter a number between 0.3 and 0.4 as these are rough estimates of hardwood kiln efficiency.

\section{Kiln Investment Cost}

This is an estimate of the turn-key cost of buying and installing the kiln building, fans, and any other related kiln equipment which must be purchased. This value should be obtained from the kiln manufacturer. Do not include the cost of the boiler or predrier in this cost.

\section{Kiln Operating Cost}

From the kiln manufacturer obtain an estimate of the annual operating cost for the kiln only. This does not include fuel cost for heating but does include electricity to run the fans, labor, and maintenance costs.

\section{Number of Operating Days}

This is an estimate of the number of days the kiln will be operating annually. Be sure to allow for loading, unloading, maintenance, and unscheduled downtime in this estimate.

\section{Boiler Size}

This is simply the size in boiler horsepower of the boiler you plan to buy.

\section{Boiler Efficiency}

From the boiler manufacturer obtain an estimate of the boiler operating efficiency. This should not include loss in efficiency due to moisture content of the fuel, only losses due to radiation and other unaccounted for losses.

\section{Boiler Investment Cost}

This is an estimate of the turn-key cost for the boiler and related equipment. This should include fuel handling equipment, air pollution control, steam lines, and any other related costs. This estimate should be obtained from the boiler manufacturer.

\section{Boiler Operating Cost}

From the boiler manufacturer obtain an estimate of the annual operating cost of the boiler. This should not include fuel costs except electricity. This should include labor and maintenance. 


\section{Predrier}

Will you predry or air-dry your lumber before putting it in the kiln? Please answer "yes" or "no" to this question. If you will not predry your lumber down to 20 percent MC, answer NO.

\section{Predrier Investment Cost}

If you purchase a predrier or buy land to air-dry, enter the initial cost here. This cost should include all items associated with the predrier.

\section{Predrier Operating Cost}

If you purchase a predrier, obtain an estimate of the annual operating cost, including power and labor, to run it.

\section{Number of Woods}

Enter here the number of species of timber you will dry in your dry kilns. Enter only species which you will dry on a fairly regular basis. This number must be between 1 and 12 .

\section{Woods Produced}

Here you enter the names of the number of woods you have chosen in the previous question. There are 12 woods which you may choose from. The names of these are given in Table 1 . These 12 woods cover all of the most commonly kiln dried woods in West Virginia.

\section{Table 2.}

Woods which may be entered in the program.

\begin{tabular}{ll}
\hline \hline Red Oak & White Oak \\
Hard Maple & Soft Maple \\
Yellow Poplar & Birch \\
Ash & Cherry \\
Walnut & Beech \\
Basswood & Butternut \\
\hline
\end{tabular}

You must enter the names of the woods you will dry exactly as they appear on the list. Make sure you enter only woods which you will dry in the kiln.

\section{Number of Thicknesses}

Here enter the number of thicknesses of lumber you will dry in the kiln. For example, if you cut $4 / 4^{\prime \prime}, 6 / 4^{\prime \prime}$, and $8 / 4^{\prime \prime}$ lumber, you will enter a 3 here. This number must be between 1 and 7 .

\section{Thicknesses Produced}

Here you will enter the size of the thicknesses you will cut and dry in the kiln. The thicknesses you may use are: $4 / 4,5 / 4,6 / 4,8 / 4,10 / 4,12 / 4$, and $16 / 4$. If 
you are cutting a thickness which does not appear on the list, choose the one which is closest to the actual size. Please enter the thicknesses exactly as they appear on the list.

\section{7-20. Lumber Volumes and Prices}

In this portion of the program you will be asked whether or not you cut each thickness you have entered, for each wood you have entered. If you answer "no," the program will go on to the next thickness. If you answer "yes," the program will ask for the volume you cut, current receiving price, and kiln dried price for each grade of that thickness and species. You may use worksheet A-2, which is given in the appendix of this user's guide, to help you organize the data. Make copies of the worksheet and use one page for each wood you produce. Enter the name of the wood at the top of the page. Enter the thicknesses of this wood which you cut in the thickness column and fill in the remaining columns for each grade of each thickness. The volume should be entered in MBF (thousand board feet) and should include only lumber which will be kiln dried. The current price is the price you are receiving now for this type of lumber. If you sell the lumber green, enter the green price here. If you sell it air-dried, enter the air-dried price. The kiln-dried price is the price you would receive if you sold the lumber as kiln dried.

\section{Initial Moisture Content}

Here you will enter the moisture content at which you expect to put the lumber into the kiln. The value of this number depends on whether or not you plan to predry or air-dry the lumber. Enter this number as a decimal. For example, you would enter a 0.45 if you were going to put the lumber in the kiln at 45 percent $\mathrm{MC}$.

\section{Final Moisture Content}

This is the moisture content at which you will take the lumber out of the kiln. Enter this number as a decimal.

\section{3-25. Residue Production}

Here you will be asked the number of tons of bark, chips, and sawdust you produce annually. If you run the program once and find that you have plenty of useable heat available from your residues, you may wish to run it again and enter a " 0 " for one of the residues. This will tell you if you could sell part of your residue and still have enough heat to operate the kilns.

\section{6-28. Residue Moisture Content}

To answer these three questions you will need an estimate of the moisture content of your residues. This estimate may be obtained by taking a representative sample of at least one cup of each type of residue. Place the residue in a metal container of known weight and weigh it. By subtracting the weight of the container from the total weight you will have the wet weight of the residue. Now place the residue into a 220 -degree Farenheit oven until it reaches 
a constant weight. To test for constant weight, weigh the samples every two hours until the weight does not change. When the samples reach a constant weight record the final weight of each type of residue. Remember to subtract the weight of the container. Moisture content on the dry basis is determined as follows:

$$
\begin{aligned}
\text { Moisture content } & =\frac{\mathrm{Ww}-\mathrm{Wf}}{\mathrm{Wf}} \\
\text { where: } \mathrm{Ww} & =\text { wet weight of sample } \\
W f & =\text { final weight of sample }
\end{aligned}
$$

These moisture contents should be entered as decimals.

\section{Revenues from Residue}

Here you will enter the amount of money you receive annually from selling your residue. Include only money you would not receive if you were to use the residue to power your kiln. For example, if you will burn only your sawdust and bark, and will sell your chips to a paper mill, do not include the money you will receive for the chips. Only include what you could have received for the bark and sawdust.

\section{Miscellaneous Costs}

Here you will enter any previously unmentioned costs which you expect over each of the next ten years. For example, if the kiln company tells you that after seven years you will need to paint the kiln building, you would enter the cost of painting in year seven. It is important that any initial investment costs which have not been included somewhere else in the program are given in the first part of this section. Remember to include things like fork lifts, stickers, automatic stacking equipment, land, fencing, utilities, fuel handling and storage, etc. Do not include any costs which have been given somewhere else in the program. An important cost which should be included in year zero is initial inventory cost. In year one you may want to enter an estimate of accounts receivable, but this should only be entered in year one.

\section{Effective Tax Rate}

Here enter as a decimal your effective tax rate. This can be computed by the following formula:

$$
\begin{array}{r}
\text { Effective tax rate }=F(1-S)+S \\
\text { where: } F=\text { federal marginal tax rate } \\
S=\text { state marginal tax rate }
\end{array}
$$

This rate should be around 0.5 and should be entered as a decimal. This is the income tax rate, not the $\mathrm{B} \& \mathrm{O}$ tax rate.

\section{2-34. Depreciation}

In these three questions you will enter the amount of the capital investment which will be depreciated over 3, 5, and 10 years, respectively. You should consult an IRS representative or look in the tax laws to determine which 
investments go in each category. As a general rule of thumb, machinery with a useful life of four years or less will go in the three-year class. All other machinery will go in the five-year class and buildings and other real estate will go in the ten-year class. Land is not a depreciable item.

\section{Investment Tax Credit}

You have a choice of taking the full investment tax credit of 10 percent or the reduced investment tax credit of 8 percent. Enter a " 10 " or an " 8 " to pick which one you choose. If you do not have any reason to choose otherwise, take the full credit of 10 percent as this is usually the best alternative. You may try the reduced credit when the sensitivity analysis is performed.

\section{Loan Interest Rate}

Here you should enter the annual interest rate which applies to any money borrowed to finance this project. Enter as a decimal.

\section{Loan Period}

Here you will enter the number of years you will take to pay back the loan mentioned in the previous section. You may enter a number between 0 and 30 . Only the first ten years will be used in the economic analysis.

\section{Amount Borrowed}

This is the amount of money borrowed to finance the project. This will equal the total investment cost of the project less the amount your company will supply from savings.

\section{Savings Rate}

This is the interest rate at which you can invest money instead of using it in this project. Enter as a decimal.

\section{Desirable Rate of Return}

This is the rate of return which your company requires in order to accept a project. This value should be no less than the weighted average cost of capital which is computed and given by the program. This is often called the minimum attractive rate of return (MARR) or the guiding rate of return.

\section{How to Load and Run the Program}

To run EERS all you need to do is boot the diskette. This can be done by putting the diskette in the disk drive and turning on the computer. If the computer is already on, you can put the diskette into the drive and type "PR\#6". Once you have done this you will see a few screens of instructions. There is a pause after each screen and you must press a key on the keyboard to continue. Be sure not to press the reset key at any time during the program or you will have to start over. Also be careful to press only one key at a time when the program instructs you to press any key to continue. Do not press any keys until you are instructed to do so by the program. 
Make sure that the printer is on and full of paper before you start if you plan to use the printer. You will be given the option to turn the printer on or off for each run of the analysis.

If you have trouble getting the program to boot and run automatically, try booting with the operating system and putting the EERS diskette into the drive and typing "RUN HELLO". This problem may arise if you own a newer Apple IIe. If you have trouble getting good output on the printer, make sure the printer is set to print 40 columns and that the screen is active while the printer is active. This may be done by consulting the user's manual that came with the printer and making the proper dip switch settings in the computer and printer.

\section{Interpreting the Output}

\section{A. Revenues}

For each species of wood produced the annual revenues are given based on current production levels and the current green or air-dried price. Expected revenues are given on the basis of current production levels and the expected kiln-dried price. The marginal revenue is the amount of additional revenue which you will receive if you undertake the kiln-drying project at current production levels.

\section{B. Kiln Capacity}

This estimate of the required kiln capacity is given only as a reference to check against your proposed kiln capacity. If this value is much larger than the proposed kiln capacity, you should double check to see if your proposed kiln capacity will handle your current production level of economically dryable timber. If this value is much smaller than the proposed kiln capacity, you may want to consider reducing the capacity or increasing the production level.

\section{Useable Heat Requirements}

This is the amount of heat in the kiln you will need annually to dry the lumber at current production levels. This is based on the kiln efficiency given and the estimated drying time of your species and thickness mix. The number of operating days annually will also affect this value.

\section{Energy Available}

The energy available from current residues is given based on residue volume, species, and moisture content. The boiler efficiency is also considered in this estimate.The energy available in each of the residues may be compared to the useable heat requirements to determine whether all or part of the residue is needed for kiln drying. Any remaining residue may be sold or disposed of by current means. If the total energy available is less than the required useable heat, you may need to purchase additional residue to supply the boiler. 


\section{E. Loan Repayment}

The loan repayment schedule gives the interest and principal payments as well as the remaining balance on the loan for each year of the loan term. This schedule is only an estimate since it is based on the loan interest rate compounded yearly.

\section{F. Yearly Cash Flow Summary}

Cash flow tables will be given in two forms. The first is an item by item breakdown for each of the ten years in the analysis. This form is useful in reviewing how all of the important cash flow items look for any given year in the analysis.

\section{G. Itemized Cash Flow Summary}

The second form of cash flow table is a yearly breakdown for each of the seven cash flow items (revenues, expenses, depreciation, taxes paid, after tax profit, cash flow, interest paid). This form of table is useful in following the progress of one particular item throughout the life of the project.

\section{H. Economic Decision Criteria}

This program will give several economic decision criteria which the user may interpret to determine whether or not a project is economically feasible. The most important of these criteria are the NPV, IRR, and B/C. These three criteria all take into account the time value of money and will rank projects identically. If the NPV is greater than 0 , then the project is desirable in the sense that it will return money to the company at a rate greater than the desirable rate of return. In the same sense, if the IRR is greater than the desirable rate of return, then the project is desirable. If the $\mathrm{B} / \mathrm{C}$ is greater than 1 , then the project is desirable. If these three criteria are not met, then the project is not desirable.

The remaining criteria (payback period, ROI, average net pre-tax profit, and average ROI) were given as additional decision information for the user and should not be used singularly to accept or reject a project.

\section{Current Inputs and Parameters}

When the printer is being used a list of important inputs and program parameters will be printed out at the end of each analysis. This is done so the user will know the values of variables used in each analysis. This will be useful if the sensitivity analyses are used.

\section{Sensitivity Analysis}

After the first analysis is complete, the user will have the choice of ending the program or running sensitivity analyses on the original data. Any or all of the original data may be changed in the sensitivity analysis. Once all the variables are changed as desired, the analysis is executed again and the output is given. The user has the option of turning the printer on or off for each run of the 
analysis. The analysis may be repeated as many times as the user desires.

During the first run of the analysis, all of the cost and revenue data are held static throughout the entire ten-year planning horizon. In other words, an inflation rate of zero percent is assumed for all costs and revenues. In the sensitivity analysis, the user will have the option to change these inflation rates to positive or negative (for deflation) values. The costs and revenues are broken down item by item and each may be assigned its own rate. The program can end only when the user chooses to end it.

\section{Worksheet A-1: Data Preparation Sheet}

1. Kiln Capacity

2. Kiln Efficiency

3. Kiln Investment Cost

4. Kiln Operating Cost

5. Number of Operating Days

6. Boiler Size BHP

7. Boiler Efficiency

8. Boiler Investment Cost

9. Boiler Operating Cost

10. Predrier yes / no

11. Predrier Investment Cost

12. Predrier Operating Cost

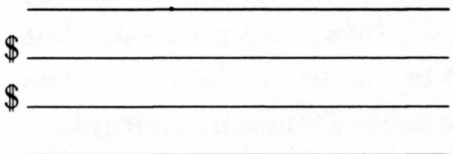

13. Number of Woods

14. Woods Produced

15. Number of Thicknesses

16. Thicknesses Produced

17-20. Lumber Volume and Prices (Use Worksheet A-2)

21. Initial Moisture Content

22. Final Moisture Content

23-25. Residue Production

Tons of Bark

Tons of Chips

Tons of Sawdust 
26-28. Residue Moisture Content

Bark

Chips

Sawdust

29. Revenues from Residue

$\$$

30. Miscellaneous Costs

Initial Investment

Year 1

Year 2

Year 3

Year 4

Year 5

Year 6

Year 7

Year 8

Year 9

Year 10

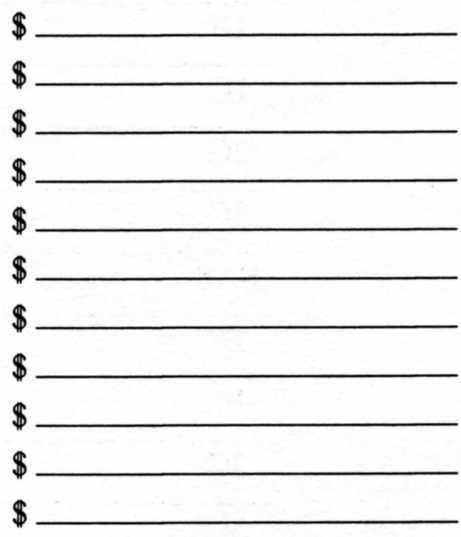

31. Effective Tax Rate

32-34. Depreciation

$$
\begin{aligned}
& \text { 3-Year } \\
& \text { 10-Year } \\
& \text { 10-Year }
\end{aligned}
$$

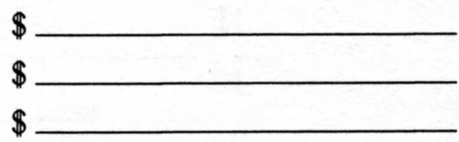

35. Investment Tax Credit

36. Loan Interest Rate

37. Loan Period

38. Amount Borrowed

$10 / 8$

39. Savings Rate

40. Desirable Rate of Return 


\section{Worksheet A-2: Lumber Volume and Prices}

Wood:

\begin{tabular}{|c|c|c|}
\hline \multirow{2}{*}{ Thickness } & Grade Volume (MBF) & $\begin{array}{cc}\text { Current Price } & \text { Kiln Dried Price } \\
\text { Per MBF } & \text { Per MBF }\end{array}$ \\
\hline & \multicolumn{2}{|l|}{ FAS } \\
\hline & \multicolumn{2}{|l|}{$1 \mathrm{~F}$} \\
\hline & \multicolumn{2}{|l|}{$1 \mathrm{C}$} \\
\hline & \multicolumn{2}{|l|}{$2 \mathrm{C}$} \\
\hline & \multicolumn{2}{|l|}{$3 \mathrm{C}$} \\
\hline & \multicolumn{2}{|l|}{ FAS } \\
\hline & \multicolumn{2}{|l|}{$1 \mathrm{~F}$} \\
\hline & \multicolumn{2}{|l|}{$1 \mathrm{C}$} \\
\hline & \multicolumn{2}{|l|}{$2 \mathrm{C}$} \\
\hline & \multicolumn{2}{|l|}{$3 C$} \\
\hline & \multicolumn{2}{|l|}{ FAS } \\
\hline & \multicolumn{2}{|l|}{$1 \mathrm{~F}$} \\
\hline & \multicolumn{2}{|l|}{$1 \mathrm{C}$} \\
\hline & \multicolumn{2}{|l|}{$2 \mathrm{C}$} \\
\hline & \multicolumn{2}{|l|}{$3 \mathrm{C}$} \\
\hline & \multicolumn{2}{|l|}{ FAS } \\
\hline & \multicolumn{2}{|l|}{$1 \mathrm{~F}$} \\
\hline & \multicolumn{2}{|l|}{$1 \mathrm{C}$} \\
\hline & \multicolumn{2}{|l|}{$2 \mathrm{C}$} \\
\hline & \multicolumn{2}{|l|}{$3 \mathrm{C}$} \\
\hline & \multicolumn{2}{|l|}{ FAS } \\
\hline & \multicolumn{2}{|l|}{$1 \mathrm{~F}$} \\
\hline & \multicolumn{2}{|l|}{$1 \mathrm{C}$} \\
\hline & \multicolumn{2}{|l|}{$2 \mathrm{C}$} \\
\hline & $3 \mathrm{C}$ & \\
\hline
\end{tabular}




\section{Literature Cited}

1. Armstrong, J.P. 1984. Lumber drying in West Virginia; results of an industry survey. West Virginia University Agricultural and Forestry Experiment Station Bulletin 689. Morgantown, W.Va.

2. Hanks, L.F., G.L. Gammon, R.L. Brisbin, and E.D. Rast. 1980. Hardwood log grades and lumber grade yields for factory lumber logs. USDA Forest Service. Northeastern Forest Experiment Station Research Paper NE468. Broomall, Pa.

3.Hardwood Market Report. 1971-1984. Hardwood market report; lumber news letter. Memphis, Tenn.

4. Metz, M.A. 1985. Concentration-dry kiln enterprise in Nicholas County, WV: a feasibility study. Unpublished MS thesis, West Virginia University, Morgantown, W.Va.

5. Shottafer, J.E., and C.E. Shuler. 1974. Estimating heat consumption in kiln drying lumber. University of Maine. Life Sciences and Agriculture Experiment Station Technical Bulletin 73. Orono, Maine.

6. U.S. Department of Energy. 1982. 1982 Annual energy outlook. U.S. Department of Energy, DOE/EIA-0383. Washington, DC.

7. Wengert, E.M. 1974. How to reduce energy consumption in kiln-drying lumber. USDA Forest Service. Forest Products Laboratory Research Note FPL-0228. Madison, Wisc. 


\section{[Blank Page in Original Bulletin]}


[Blank Page in Original Bulletin] 
